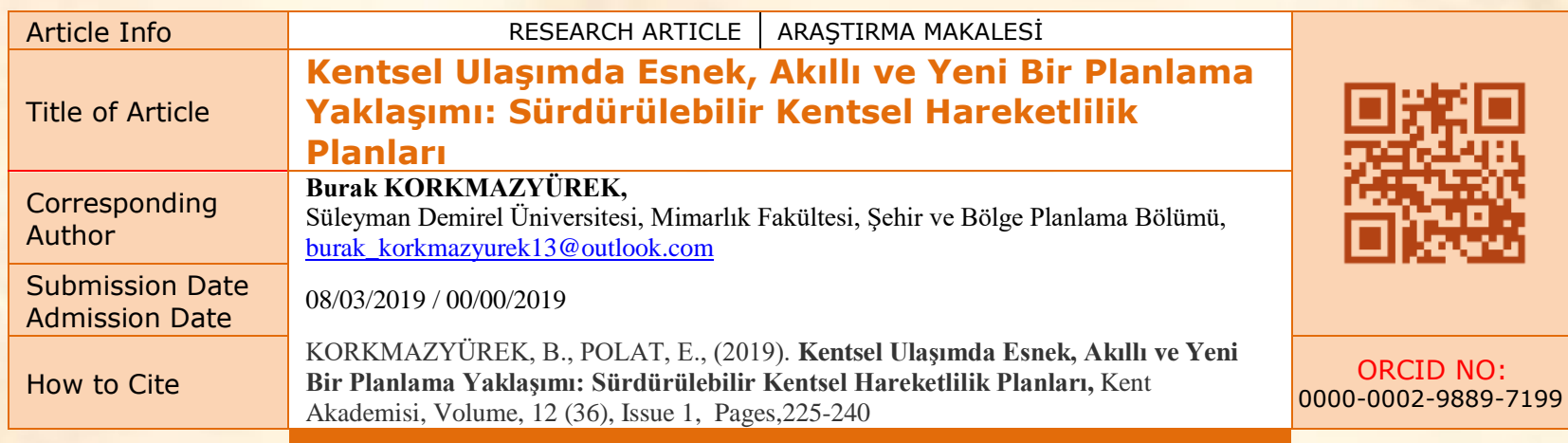

\title{
Kentsel Ulaşımda Esnek, Akıllı ve Yeni Bir Planlama Yaklaşımı: Sürdürülebilir Kentsel Hareketlilik Planları
}

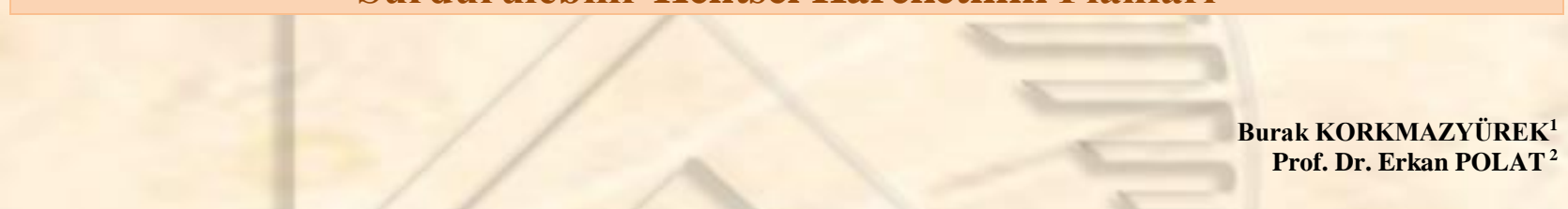

\section{ABSTRACT}

Urbans; as a result of direct/indirect and positive/negative effects caused by rapidly increasing population and development pressures, they seem to be an organism advancing by consuming natural resources and production areas. The effort to control cities through all its known aspects and through the means of planning means this complex and dynamic structure is insufficient as it involves life and mobility itself.

Mobility is generally perceived as vehicle-based transportation based on physical infrastructure. For this reason, planners, all relevant institutions / organizations and those responsible are responding to the needs of the urban by means of physical infrastructure based arrangements with optimum transportation analysis. However, the interrelationship between physical and point analysis and vehicle use becomes inefficient after a certain urban threshold, and the desired permanent and sustainable targets cannot be reached. In this respect, a sustainable, integrated, flexible, intelligent and new transportation planning approach was needed to increase the quality of life, especially in the 2000s. This process was followed by the presentation of the Urban Mobility Action Plan and Sustainable Urban Mobility Plans as an alternative to the solution of these problems in 2009 with the contribution of the European Union (EU) and the European Commission (EC).

In urban transportation, in the urbans of the world, especially in the European continent, in the last quarter century, it is observed that Sustainable Urban Mobility Plans are researched and used together with an effective evaluation process in the analysis of urban transportation problems. In this article, Sustainable Urban Mobility Plans which are flexible, smart and new planning approach are evaluated in urban transportation. Sustainable Urban Mobility Planning, mobility-related concepts are discussed together with their Turkish counterparts, targeted development in Turkey Sustainable Urban Mobility Plan guide the original literature is pursued.

The theoretical conclusion is that Sustainable Urban Mobility Plans are one of the most effective planning tools in urban transport. Of urbans in Turkey; It should take care of the original Sustainable Urban Mobility Plan in the preparation, planning, implementation and monitoring processes and solve the problems related to transportation and thus increase the quality of urban life in this way.

${ }^{1}$ Süleyman Demirel Üniversitesi, Mimarlık Fakültesi, Şehir ve Bölge Planlama Bölümü, burak_korkmazyurek13@outlook.com, gsm: (5372641384) Süleyman Demirel University, Faculty of Architecture, Department of City and Regional Planning, burak_korkmazyurek13@outlook.com

${ }^{2}$ Süleyman Demirel Üniversitesi, Mimarlık Fakültesi, Şehir ve Bölge Planlama Bölümü, erkanpolat@sdu.edu.tr, gsm: (5052695610)

Süleyman Demirel University, Faculty of Architecture, Department of City and Regional Planning, erkanpolat@sdu.edu.tr 
KEYWORDS: Sustainability, Urban Transportation, Mobility, Urban Mobility, Sustainable Mobility

\section{ÖZ}

Kentler; hızla artan nüfus ve gelişme baskılarından kaynaklanan doğrudan/dolaylı ve olumlu/olumsuz etkiler sonucunda doğal kaynakları ve üretim alanlarını tüketerek ilerleyen birer organizma görünümündedirler. Kentleri bilinen tüm yönleriyle ve planlama araçları vasıtasıyla kontrol etme çabası, bu karmaşık ve dinamik yapı yaşamın ve hareketliliğin kendisini içerisinde barındırdığından yetersiz kalmaktadır.

Hareketlilik, genel anlamda fiziksel altyapıya dayalı araç odaklı ulaşım olarak algılanmaktadır. Bu sebeple planlamacılar, ilgili tüm kurum/kuruluş ve sorumlular, optimum ulaşım çözümlemeleri ile kentin gereksinimlerine fiziki altyapıya dayalı düzenlemelerle cevap vermektedirler. Ancak fiziki ve noktasal çözümlemeler ile araç kullanımı arasındaki karşılıklı ilişki belirli bir kentsel eşikten sonra verimsiz hale gelmekte, elde edilmek istenen kalıcı ve sürdürülebilir hedeflere erişilememektedir. Bu doğrultuda özellikle 2000'li yıllarda yaşanan kırılmayla birlikte yaşam kalitesini arttırmak için sürdürülebilir, entegre, esnek, akıllı ve yeni bir ulaşım planlama yaklaşımına ihtiyaç duyulmuştur. Bu süreci 2009 yılında Avrupa Birliği (AB) ve Avrupa Komisyonu'nun (AK) da katkılarıyla Kentsel Hareketlilik Aksiyon Planı ve Sürdürülebilir Kentsel Hareketlilik Planlarının bu sorunların çözümüne bir alternatif olarak sunulması takip etmiştir.

Kentsel ulaşımda dünya kentlerinde, özellikle Avrupa kıtası kentlerinde, son çeyrek asırda, Sürdürülebilir Kentsel Hareketlilik Planlarının araştırılıp, etkin bir değerlendirme süreci ile birlikte, kentsel ulaşım problemleri çözümlemelerinde kullanıldığı gözlenmektedir. Bu makalede kentsel ulaşımda, esnek, akıllı ve yeni bir planlama yaklaşımı olan Sürdürülebilir Kentsel Hareketlilik Planları değerlendirilmektedir. Sürdürülebilir Kentsel Hareketlilik Planlaması, hareketlilikle ilgili kavramların Türkçe karşılıkları ile birlikte irdelenmekte, Türkiye'de geliştirilmesi hedeflenen özgün Sürdürülebilir Kentsel Hareketlilik Planı rehber literatürü oluşturulmaya çalışılmaktadır.

Bu nedenle çıkarılan teorik sonuç, Sürdürülebilir Kentsel Hareketlilik Planlarının kentsel ulaşımda en etkili planlama araçlarından biri olduğudur. Türkiye'de kentlerin; özgün Sürdürülebilir Kentsel Hareketlilik Planı çalışmalarını hazırlık, plan, uygulama ve izleme süreçleriyle ele alıp, ulaşım temelli sorunlarını çözerek, kentsel yaşam kalitesini bu yolla arttırması gerekmektedir.

ANAHTAR KELIMELER: Sürdürülebilirlik, Kentsel Ulaşım, Hareketlilik, Kentsel Hareketlilik, Sürdürülebilir Hareketlilik

\section{"Kentsel Ulaşımda Esnek, Akıllı ve Yeni Bir Planlama Yaklaşımı: Sürdürülebilir Kentsel Hareketlilik Planları"}

\section{GíRIŞ}

Kentler doğal ve yapay bileşenlerin ortak hareket ettiği dinamik ve karmaşı bir yaşam döngüsüne sahiptir. Kentlerin bu örüntüsü, hareketlilik olarak ifade edilen coğrafi yer değiştirmeleri, bu eylemleri gerçekleştirme isteği bulunan hareketlileri ve ihtiyaç duyulan tüm nesneleri de içerisinde barındırmaktadır. Kentte hareketliliği oluşturan unsurlar iki ana başlıkta toplanmaktadır. İlki yayaların hareketliliği, ikincisi ise çeşitli amaçlarla kullanılan araçların hareketliliğidir. Kentte gerçekleşen hareketlilik eylemleri ve bileşenlerinin tümü ise kentsel hareketliliği meydana getirmektedir.

Dünyada olduğu gibi Türkiye'de de kentsel hareketlilik araç odaklı hareketlilik olarak algılanmaktadır. Dolayısıyla planlama çalışmaları, artan araç hareketliliğinin getirdiği doğrudan/dolaylı sorunlara çözüm arayışı ile temellenmektedir. $\mathrm{Bu}$ arayış ise ulaşım altyapısının arttırılması ve kentsel işlevsel alan kullanımlarının, araç odaklı düzenlemeler sebebiyle ikinci planda kalmasıyla sonuçlanmaktadır. Ayrıca ülke politikalarının petrol kullanımı ve enerji tüketimi üzerine kurulduğu modern kentlerde araç odaklı düzenlemelerin yapılması da normal görülmektedir. Fred Kent ${ }^{3}$ bu düzenlemelerin olumsuzluğuna, kentleri araç ve ulaşım odaklı planlarsanız, araç ve ulaşım elde edersiniz insanları ve mekânları planlıyorsanız, insanları ve mekânları edinirsiniz sözü ile dikkat çekmekte, insan ve

\footnotetext{
${ }^{3}$ Fred Kent: Kentsel alanları yeniden canlandırmak ve yaşanabilirlik, akıllı büyüme ve kentlerin geleceği konusunda önde gelen düşünürlerden biridir. Aynı zamanda Kamusal Alanlar Projesi'nin de (Project for Public Spaces - https://www.pps.org/) kurucusudur.
} 
mekân odaklı planlamaya vurgu yapmaktadır. Kentsel ulaşımdan kaynaklı bu sorunlar dünyada olduğu gibi Türkiye'de de, artan bireysel araç kullanımının getirdiği yansımalardır. Taşıma kapasitesinin üzerine çıkan bireysel araç kullanımı nedeniyle, kentsel yaya ve araç hareketliliği; zamanla yavaşlamakta bir süre sonra ise tıkanıklıkla ve yetersizlikle karşılaşmaktadır. Türkiye'de özellikle yerel yönetimler tarafından yapılan kent planlama çalışmaları, ulaşım problemlerine çözüm önerileri getirse de; artan nüfus ve bireysel araç kullanımı, toplu taşım ağının yetersizliği, park problemleri, sürdürülebilir alternatif modların ve entegre akıllı ulaşım sistemlerinin kullanımının sağlanamaması, teknolojik ve sürdürülebilir ulaşım esaslarının benimsenememesi, planlama sürecinde yaşanan aksaklıklar ve bilgi düzeyinin yetersizliği vb. nedenlerden ulaşım problemleri çözülememekte ve yapılan yanlış uygulamalar sorunları geri dönüşü olmayacak şekilde farklılaştırmakta ve arttırmaktadır.

Kentsel ulaşımdan kaynaklı sorunları ele alırken, modernleşmenin ve modern kentin ihtiyaçlarının getirdiği zaman ve hız algısının etkisinden ve aralarındaki çelişkiden de söz etmek gerekmektedir. Kentler zamanın en hızlı tüketildiği yapıları temsil etmekte ve aynı gün içerisinde birçok işlevsel alanı bir arada kullanma imkânı vermektedir. Bu nedenle sürekli olarak bir olaya ya da bir işe yetişme durumunda kalınan kentlerde, hızlanmak, hızla ulaşmak isteği oluşurken, bir yandan da artan ulaşım problemleri sebebiyle bireysel araç kullanımını azaltıp, trafiği çeşitli araç ve yöntemlerle yavaşlatmak için çaba sarf edilmektedir. Bu çelişkiden hareketle çıkarılabilecek en optimum seçim; kent sakinlerine hem bireysel araç kullanımını azaltmayı vadeden, hem kısa mesafede en hızlı ulaşımı sağlayan, (böylelikle en verimli arazi kullanımını biçimlendiren) bireyleri önemseyen ve onların hareketine öncelik tanıyan seçim olmaktadır. Bu hassasiyetle özellikle Avrupa ve Amerika kıtası kentlerinde yeni bir çözüm arayışına gidilmektedir. Bilinen geleneksel ulaşım planları ${ }^{4}$ yerine "Sürdürülebilir Kentsel Hareketlilik Planları (Sustainable Urban Mobility Plans (SUMP))" geliştirilerek kentsel ulaşım problemlerine çözüm aranmaya çalışılmaktadır. Bu çözüm arayışları Avrupa kıtasında özellikle 2000'li yıllarda başlamıştır. Bu yıllarda AB ülkelerinin kentleri ulaşım problemleriyle yüz yüze gelmiş ve bu problemleri Ulaşım Ana Planları ile çözemedikleri için, (Türkiye'deki gibi) AK 2009 yılında Kentsel Hareketlilik Aksiyon Planı ile Sürdürülebilir Kentsel Hareketlilik Planlarını (SKHP) bu sorunların çözümüne bir alternatif olarak sunmuştur (Yerli, 2015).

Dünyada olduğu gibi Türkiye kentlerinde de, hızlı nüfus artışı sonucu kentlerin aşırı büyümesi, dolayısıyla ulaşılması gereken mesafenin artması bireysel araç kullanımını arttırmaktadır. Bu gelişmeler üzerine alternatif sürdürülebilir ulaşım çözümlerinin geliştirilmesi zorunlu hale gelmiştir. Türkiye'de ulaşım problemlerine çözüm arayışı güncel çalışmaların gerisinde hâlihazırda geleneksel ulaşım planlama esaslarına göre sürdürülmektedir. SKHP geliştirme çalıșmaları Türkiye'de bazı uygulamalarla başlatılmaya çalıșılıyorsa da, bu yeni planlama anlayıșı yeterince araştırılmamıştır. Özellikle bu planlama anlayışının Türkiye'deki planlama süreçleri içerisinde yer almasına gerek olup olmadığı, yer alacaksa nasıl entegre olması gerektiği irdelenmelidir. Bu bağlamda SKHP'i Türkiye özelinde irdeleyen özgün bir çalışma bildiğimiz kadarıyla bulunmamaktadır. ${ }^{5}$

\section{Makalenin Amaç ve Yöntemi}

$\mathrm{Bu}$ makalenin amacı, ulaşım planlamasında esnek, akıllı ve yeni bir yaklaşım olan ve Türkiye dışındaki kent koşullarına göre geliştirilen SKHP'nin plan modeli ve sürecinin araştırılması ile geleneksel ulaşım planından farklarının anlaşılarak Türkiye'de geliştirilmesi hedeflenen özgün SKHP rehber literatürüne katkıda bulunulmasıdır. Bu doğrultuda makalenin kapsamını ise; hareket, mobilite (hareketlilik) ve motilite (kendiliğinden hareket etme) kavramlarının kökeni, kentsel hareketlilik ve SKHP'nin değerlendirilmesi oluşturmaktadır. Makale SKHP konusunda çalışma yürüten önemli yerli/yabancı kurum ve kuruluşlar ile birlikte nitelikli temel kaynakların irdelenmesi yoluyla yapılmıştır. Makale Türkçe kaynakların yetersizliği ve SKHP uygulamasının temelinin Avrupa'da yapılan araştırma ve uygulamalara dayanması sebebiyle, sürdürülebilirlik, kentsel ulaşım, hareketlilik, kentsel hareketlilik ve sürdürülebilir hareketlilik planlaması temel anahtar kelimeleri ile yabancı kaynaklar üzerinden yürütülmüş ve özgün Türkçe literatürün oluşturulmasına önem gösterilmiştir.

\footnotetext{
${ }^{4}$ Dünyada bunlar; Kapsamlı Kentsel Ulaşım Planları, Ulaşım Master Planları, Kentsel Trafik Planları, Raylı Sistem Planları, Toplu Taşım Planları vb. Türkiye'de bunlar; Ulaşım Master Planları, Ulaşım Eylem Planları, Acil Eylem Planları, Raylı Sistem Planları, Otopark Planları, Ulaşım İyileştirme Etütleri vb. (Özalp ve Öcalır, 2008).

${ }^{5}$ Bu makale Burak KORKMAZYÜREK tarafından Prof. Dr. Erkan POLAT danışmanlığında 2018 yılında Süleyman Demirel Üniversitesi Fen Bilimleri Enstitüsünde tamamlanan ve Ulusal Tez Merkezi’nde (525169) tez numarası ile kayıtlı, Türkiye'de özgün SKHP çalışmalarına temel oluşturalabilecek "Kentsel Ulaşım Politikaları Kapsamında Sürdürülebilir Kentsel Hareketliliğin Değerlendirilmesi" adlı yüksek lisans tezinden geliştirilmiştir.
} 


\section{Nesnenin Hareketi, Mobilite ve Motilite Kavramlarının Kökeni}

Türk Dil Kurumu'na göre nesne; belli bir ağırlığı, hacmi ve rengi olan her türlü cansız varlık, şey, obje olarak tanımlanmaktadır (Türk Dil Kurumu, 2018). İngilizce karşıllğı olan "object” ise; görülen veya dokunulan ama genellikle canlı bir hayvan, bitki veya kişi olmayan bir şey olarak tanımlanmaktadır (Cambridge Dictionary, 2018). $\mathrm{Bu}$ tanımlamalardan hareketle nesnenin canlı bir varlığı ifade etmediği anlaşılmaktadır. Ancak mobilite ve motilite durumları canlı ve cansız varlıkları etkilemektedir. Harekete geçecek olan şey yani nesne, mobilite ve motilite durumlarında canlı veya cansız olabilmektedir. Bu durumda nesne makale kapsamında, içsel ve dışşal motilite etkileri ile hareketlilik işini yapan canlı ve cansız şeylerin tümü için kullanılmaktadır.

Hareket ise kelime kökeni olarak Arapçadan türemektedir. Arapça "hrk" kökünden gelen "harakat" yani "hareket etme, devinim" sözcüğünden kökenlenmektedir. Hareket nesnelerin, sermayenin, fikirlerin ve diğer bilgilerin yer değiştirmesidir. Makale kapsamında, hareket ile nesnelerin hareketi ifade edilmekte, bu sebeple İngilizce anlamlarını da (motion ya da move) göz önünde bulundurarak; hareket, canlı ve cansız nesnelerin yer değiştirmesi anlamında kullanılmaktadır. Hareket bir yere doğru yönelimlidir ve bu nedenle bir orijin ile bir veya daha fazla hedef arasında gerçekleşmektedir. Bazı durumlarda ise hareket, gerçek bir kökeni veya hedefi olmayan dolaşım eylemleridir (Kaufmann, 2012c).

Fizikte ise hareket; belirli bir referans noktasına göre cismin (canlı ya da cansız nesnenin) belirli bir zamanda yer değiştirmesidir. Burada referans noktası önemlidir. Çünkü hareket halindeki araçta oturan bir yolcu, araca göre hareket etmezken, dışarıdan bakan bir gözlemciye göre ise hareket etmektedir. Biyolojide ise hareket; bir organizmanın çeşitli kısımlarının birbirine göre durumunu ya da yerini değiştirmesidir (Türkçe Terimler Sözlüğü, 2018).

Yer değiştirme eylemi olmadan da hareket mümkündür. Örneğin; fizikte nesnelerin atomlardan oluştuğu, atomlarında sürekli hareket halinde oldukları bilinmektedir. Bu ise bir anlamda var olan her şey hareket halindedir anlamına gelmektedir. Ancak atomların sürekli hareket halinde olması ait oldukları nesnenin yer değiştirmesini gerektirmemektedir. Biyolojide ise; aynı vücudun uzuvlarının birbirlerine göre yer değiștirmesi hareket kabul edilirken, aslında vücut yer değiştirme eylemi yapmamaktadır. Bu bağlamda "hareket" kavramının motilite (atomların hareketi ya da kasların hareketi vb.) ve mobilite (konumun, bulunulan yerin daha öncekine göre değişmesi) olan tüm durumları içerisinde barındırdığı ve bunların eyleme geçmesi işinin ise "hareketlilik" olduğu yorumuna ulaşılmaktadır.

Mobilite ve motilite kavramlarının kökeni, Latince "mob/mov/mot" ek kullanımlarına dayanmaktadır. "Mob" eki "mobil vulgus (the fickle crowd)" yani "kararsız kalabalık" anlamına gelen kelimeden (Dictionary, 2018), "mov" eki "movere" yani "hareket ettirme" anlamına gelen kelimeden (Etimoloji Sözlüğü, 2018), "mot" eki ise Latince ve Eski Yunancada "motus" yani "devinim"6 anlamına gelen kelimeden köklenmektedir (Türkçe Terimler Sözlüğü, 2018).

“Mob/mov/mot” ek kökenleri Latinceden İngilizceye 1600’lü yıllarda geçmiştir (Etymology Dictionary, 2018.). Her biri İngilizcede "move" kelimesini ifade etmektedir (Quia Web, 2018). Bu kelime İngilizcede; bir sebeple pozisyon değiş̧irme, hareket ya da yaşamak veya çalışmak için farklı bir yere gitmek anlamlarında kullanılmaktadır (Cambridge Dictionary, 2018). "Mob/mov/mot" ek kökenlerinden türeyen mobilite ve motilite kavramları incelenecek olursa; mobilite kavramının "mobile" ve "ability" kelimelerinin ortak kullanımından türetildiği anlaşılmaktadır. "Mobile" kelimesi İngilizcede; serbestçe hareket etmek ve yürümek, bir yerden diğerine hareket etmek anlamında kullanılmakta, "ability" kelimesi ise bir şeyi yapmak için beceri sahibi olmak anlamına gelmektedir (Cambridge Dictionary, 2018). Bu durumda mobilite kelimesi "hareketlilik, hareket edebilme, hareketli olma" anlamlarına gelmekte, bu ise güncel planlama çalışmalarında (özellikle ulaşım planlamasında), coğrafi olarak hareket etme niyeti ve eylemi anlamında kullanılmaktadır (Kaufmann, 2016). Mobilite kelimesi aynı zamanda; normal hareket etme, yürüyebilme, bir yerden bir yere seyahat etme anlamlarında da kullanılmaktadır (Macmillian Dictionary, 2018).

Hareketlilik terimi ise 1920 'lerde Sorokin ve Chicago Okulu'nun çalışmaları ile sosyal bilimlere girmiş ve kentsel yaşamın ayrılmaz bir parçası olarak görülmüştür (Kaufmann, 2012a). Hareketlilik kavramı birçok bilim ve alt dallarında yer alan bir kavramdır. Genel olarak, yer değiştirmek amacıyla ivme kazanan öğelerin yarattığı hareketlerin

\footnotetext{
${ }^{6}$ Devinim fizikte; durağan, durmakta olan bir noktaya göre yer değiştirmekte olan bir nesnenin yaptığı eylem anlamına gelmektedir. Türk Dil Kurumu ise devinimi; devinme işi, hareket ve yer değiştirme olarak tanımlamaktadır (Türk Dil Kurumu, 2018). "Devinme" Latince "motio" kelimesinden kökenlenmektedir. "Motio" ise aynı zamanda İngilizcede "motion” kelimesinin de kökenidir (İngilizce Latince Sözlük, 2018).
} 
bütününe verilebilecek ad olan bu kavram, kararlı ve durağan olmayan öğelerin ortaya çıkardığı durumu ifade eden bir anlam taşımaktadır (Özübal, 2009). Hareketlilik, çoğul anlamlar içeren bir terimdir (Kjærulff, 2011). Hareketlilik herhangi bir maddenin yer değiştirmesi olarak tanımlanabileceği gibi, maddenin belirli bir amaç doğrultusunda, sürekliliği olan veya olmayan, belli bir yönde veya farklı yönlerde meydana gelen yer değişim eylemleri olarak da tanımlanabilir (Kaynak, 2005). Hareketlilik ayn zamanda, hareket etme niyeti ve bu hareketin coğrafi alanda gerçekleştirilmesi olarak da tanımlanabilir (Kaufmann, 2012a). Bu anlamda "mobil olmak" bireyin planlarını ve fikirlerini farklı hareket biçimleriyle gerçekleştirmesi anlamına gelmektedir (Kjærulff, 2011). Burada hareket etme niyeti, canlı olan nesne için karar verme süreci, cansız olan nesne içinse etkilenme süreci olarak düşünülebilir. Bu makalede hareketlilik; hareket işini yapacak olan canlı ve cansız nesnenin, iç ve dış etkiler sonucunda, coğrafi alanda, fiziksel anlamda bir noktadan diğerine belirli bir amaç için yer değiştirmesi olarak tanımlanmaktadır.

Hareketlilik kısa ve uzun olmak üzere iki dönemde gerçekleşmektedir. Kısa dönemde gerçeklesen hareketlilik, insanların kentle ve birbirleri ile iletişim/etkileşim kurmaları sonucu ortaya çıkan dinamizmdir (Özübal, 2009). Kentte uzun dönemlerde kendisini hissettiren hareketlilik ise, konut, ticaret, sanayi, donatı vb. alanlarda yer alan yapıların işlevlerinin veya bu yapıların kullanıcılarının kent içerisindeki konumlarının değişmesi ile gerçeklesen hareketliliktir.

Kent yaşamının kalitesine etki eden deneyimlerden bir diğeri ise günlük hareketliliktir. Günlük hareketlilik kentsel yaşamın kalitesiyle ilgilidir. Bir taraftan işlevsel alanlara erişilirken, öte yandan hareketliliğin nasıl, ne zaman ve kiminle birlikte yapıldığının önemini yansıtmaktadır. Günlük hareketlilik, günlük seyahat deneyimlerini, ulaşım ve kent planlamayla birleştirme deneyimidir. Bu bakış açısıyla, günlük hareketlilik insanların günlük hayatlarında nasıl örgütlendiklerini, bu süreçte kentle ve ulaşım modlarıyla nasıl etkileşimde bulunduklarını anlamaya yarayan bir araç işlevi görmektedir (Dávila, 2013).

"Mot" ek kökeni ve "ability" kelimesinin ortak kullanımından türetilen motilite kavramı ise; biyoloji ve tıp dallarındaki kullanımından sosyoloji alanına geçmiştir ve "mobil olmamızı sağlayan faktörler kümesi" anlamına gelmektedir. Kavram aynı zamanda "mot" yani "hareket", "ability" yani "yapabilme" anlamlarını bir arada ifade ettiğinden; kendiliğinde hareket etme, hareket kuvveti ya da yeteneği anlamlarına da gelmektedir (Kaufmann, 2012b). Motilite; harekete geçecek olanın, kendi iç kuvveti ya da dışarıdan gelen etkiler sonucu ortaya çıkan ve aslında mobil olmayı sağlayan faktörlerin tümüdür. Motilite içsel ve dışsal etkileriyle ikiye ayrılmaktadır. Bu faktörlerin, harekete geçecek olan üzerindeki etkisi hareketliliğe dönüştüğünde ise yapılan eylem mobilite olmaktadır (Şekil 1).

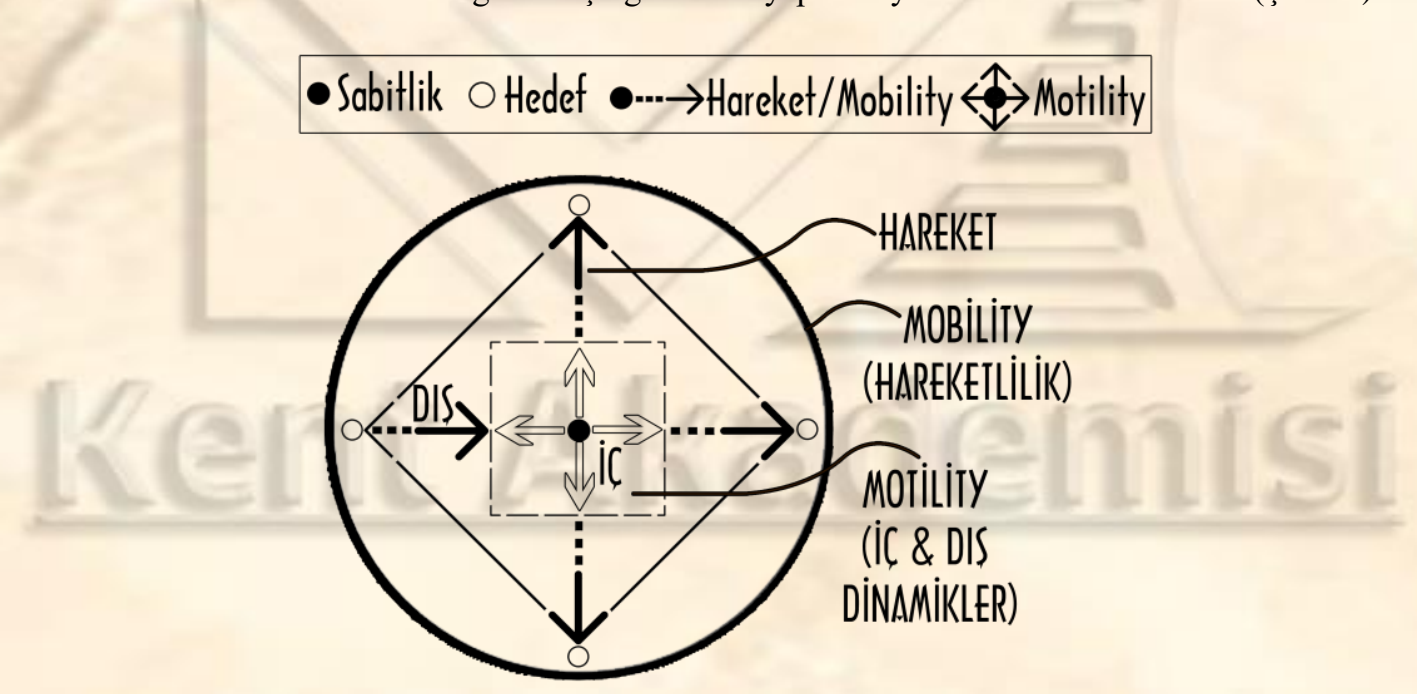

\section{Şekil 1. Mobilite ve Motilite Kavramları Arasındaki İlişki}

Vincent Kaufmann tarafından 2002 yılında kavramsallaştırılan motilite; "insanların bir yerden diğerine geçmesini sağlayan özellikler dizisi”, diğer bir deyişle, fiziksel araçlar, kazançlar, sedanter bir varoluşa ya da hareketliliğe olan istek olarak tanımlanmaktadır (Kaufmann, 2012b). Motilite, bir birey ya da grubun, hareketlilik için imkân ve becerilere sahip olması halidir (Flamm ve Kaufmann, 2006). Motilite hareketlilik potansiyeli, yani hareketliliği etkileyen erişim, beceri (kendi sahip olduklarımızla güçlendirilen veya zayıflayan beceriler, edinilen bilgi, örgütsel kapasite vb.) ve plan yapma gibi bireysel faktörlerin doğrudan tanımlayıcısıdır. Motilite bu nedenle, erişimin 
toplumsal koşullarına (arz kelimesinin en geniş anlamıyla kullanıldığı koşullar), becerilere (bu arzdan yararlanabilmek için ihtiyaç duyulan beceriler) ve dikkate alınan hareketlilik fikirlerine (arzın etkin kullanımı ile gerçekleşen fikirler) atıfta bulunmaktadır (Kaufmann, 2016).

Erişimin toplumsal koşulları, belirli bir bölgenin sunduğu çeşitli ulaşım ve iletişim seçeneklerinden ve bu seçeneklere erişim koşullarından (maliyet, lojistik vb.) yararlanabilme imkânını, beceriler, bu ulaşım ve iletişim seçeneklerine erişmek ve bunlardan yararlanmak için gerekli olan bilgi veya yetkinlikleri, hareketlilik fikirleri ise bireyler, gruplar, ağlar ve kurumların bu seçenekleri nasıl yorumladıkları ve nasıl hareket ettiklerini ifade etmektedir. Ayrıca motilite; "varlıkların (malların, bilginin, kişilerin vb.) sosyal ve coğrafi mekânda mobil olmaları veya bu varlıkların kendi koşullarına göre sosyo-uzamsal hareketlilik kapasitesine erişmeleri”" anlamına da gelmektedir (Dávila, 2013). Mobilite kavramının tersine, motilite kavramı, "hareketin ve eylemin yapısal ve kültürel boyutlarını, sosyo - mekânsal hareketliliğin gerçek ya da potansiyel kapasitesinin, farklı sosyokültürel bağlamlarda farklı sonuçlara sahip olabileceğine" vurgu yapmaktadır (Dávila, 2013).

Mobilite ve motilite kavramları arasındaki ilişki örneklerle ifade edilecek olursa, insan vücudunun eklemsel hareketi motilite ve içsel bir etki iken, eklemsel hareketler, vücudu harekete geçirip eyleme dönüştügünde yaşanan durum ise mobilite olmaktadır. Başka bir örnekte ise, koşu bandında adım atılması ilerleme sağlandığı anlamına gelmemektedir. Çünkü yer değiştirme ve hareket anlamında değerlendirme yapıldığında, aslında koşu bandındaki kişi ilerleyememektedir. Araçlar üzerinden bir örnek verilecek olursa, motoru çalışmayan bir araç hareket elde edememektedir. Ancak dışarıdan başka itici güçlerin desteğiyle yer değiştirebilmekte veya hareketlilik sağlayabilmektedir. Motorun çalışıp çalışmaması veya dışarıdan itici bir gücün desteğinin alınması durumları tamamen motilite eyleminin içsel ve dışsal etkileridir. Bu durumda örneklerden elde edilen düşünsellerle, motilite olmadan mobilite olmazken, mobilite olmadan motilite olabilir çıkarımı yapılabilmektedir. Aşağıda mobilite ve motilite kavramlarının açıklamalı köken şeması yer almaktadır (Şekil 2).

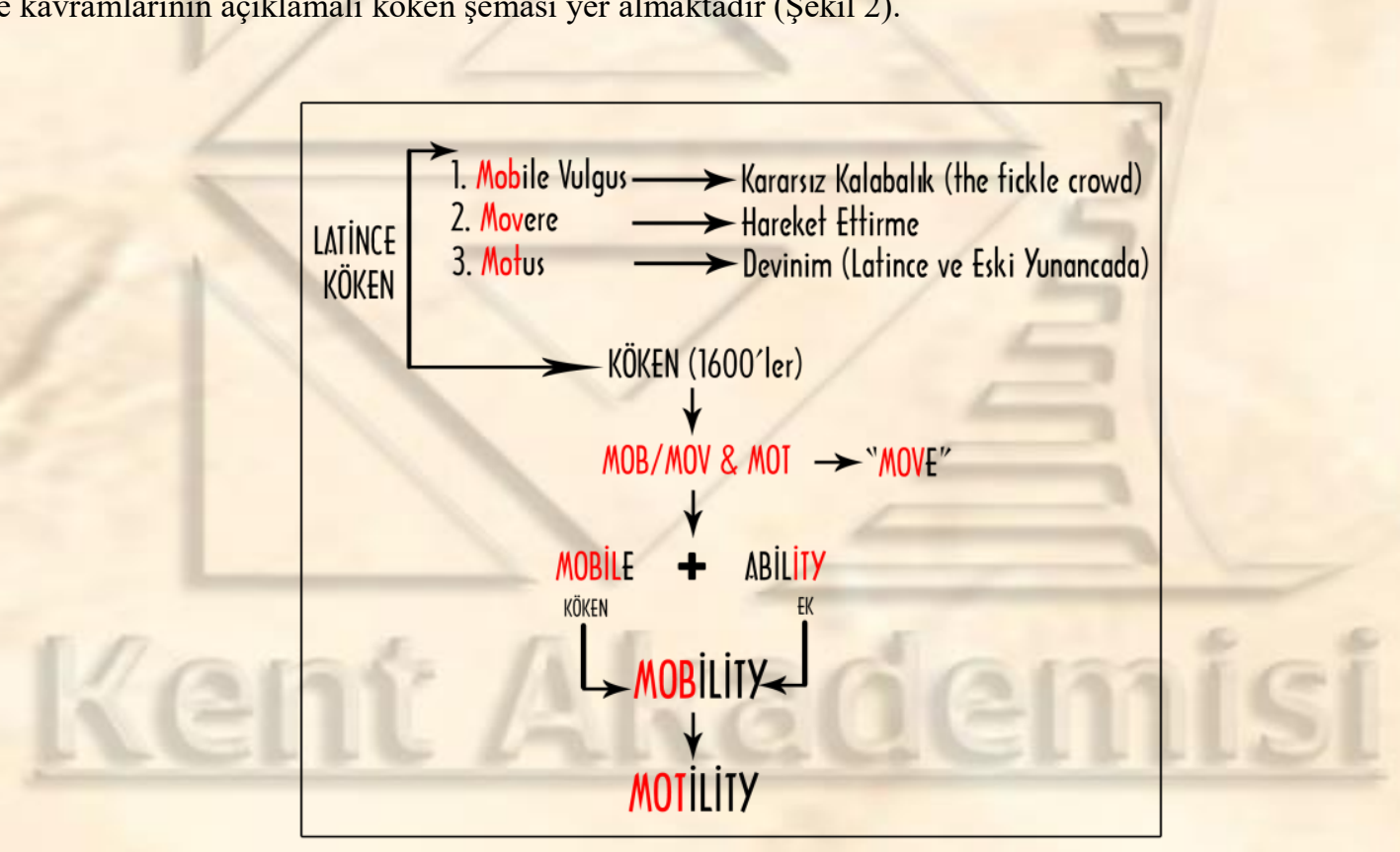

Şekil 2. Mobilite \& Motilite Açıklamalı Kavramsal Köken Şeması

Motilite olmadan mobilite olmaması durumu temel alınarak makaleye özgün kentsel ulaşım, erişilebilirlik ve ulaşılabilirlik tanımlamaları getirilmektedir. Bir örnekle ifade edilecek olursa; bir futbol topunun harekete geçebilmesi, içsel ya da dıştan gelen başka bir etkenle mümkün olmaktadır. Bu etkenler motilite kavramının dışsal ve içsel etkileridir. Topa vurulması topu A noktasından B noktasına doğru hareket ettirmekte, bu ise "hareketlilik"i oluşturmaktadır. Örnek anlatımdan yola çıkarak tanımlanacak olursa; kentsel ulaşım; çıkışla varış noktası arasındaki eylemlerin tümüdür. Bu durumda ulaşılabilirlik; bir hareket yani motilite, erişilebilirlik ise; hareketlilik için gerekli nesnel koşullara atıf yapmakta ve mekânın ulaşım araçlarına olan bağlılığı ve orada gerçekleştirilebilecek firsatlar 
açısından yerin çekiciliğinin bir ölçüsü olarak tanımlanmaktadır (Ohnmacht vd., 2009). Aşağıdaki şekilde motilite etkisi ile mobilite olma durumu ve kentsel ulaşımın oluşumu incelenmektedir (Şekil 3).

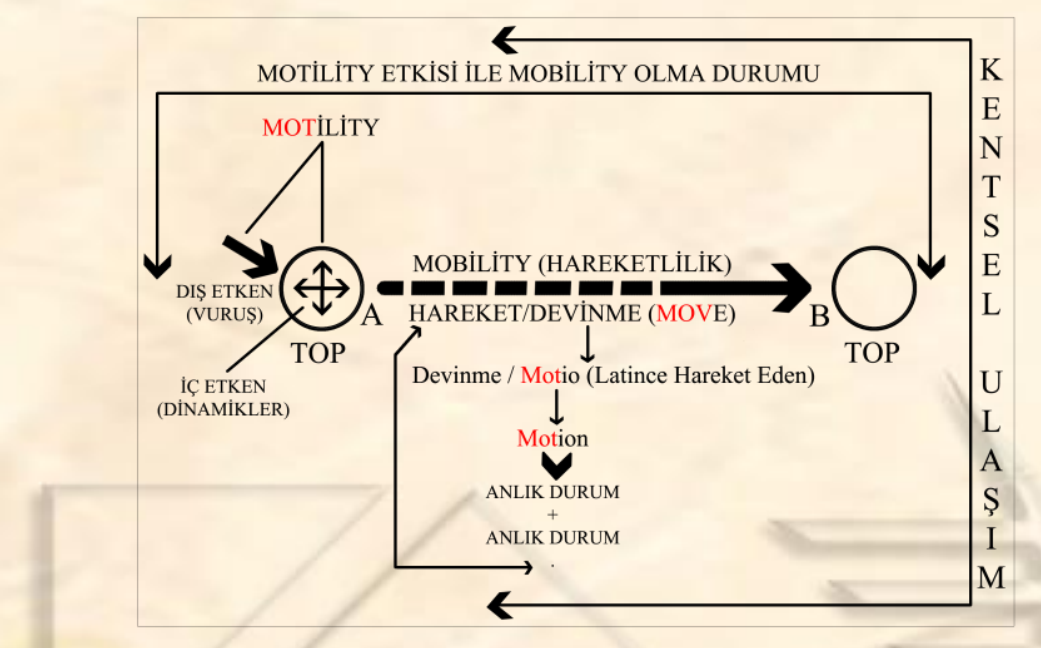

Şekil 3. Mobilite/Motilite Etkileşimi ve Kentsel Ulaşım

Kentsel ulaşımın yeniden tanımlanması, motilite ve mobilite ile doğrudan ilişkili olan yaya ve araç odaklı kentsel ulaşımın da yeniden tanımlanmasını gerektirmektedir. Yayaların, motilite etkileri ve bu etki sonucu hareket ederek mobilite hale gelmesi yaya odaklı kentsel ulaşımı, araçların bu etki ile mobilite hale gelmesi ise araç odaklı kentsel ulaşımı oluşturmaktadır (Şekil 4).

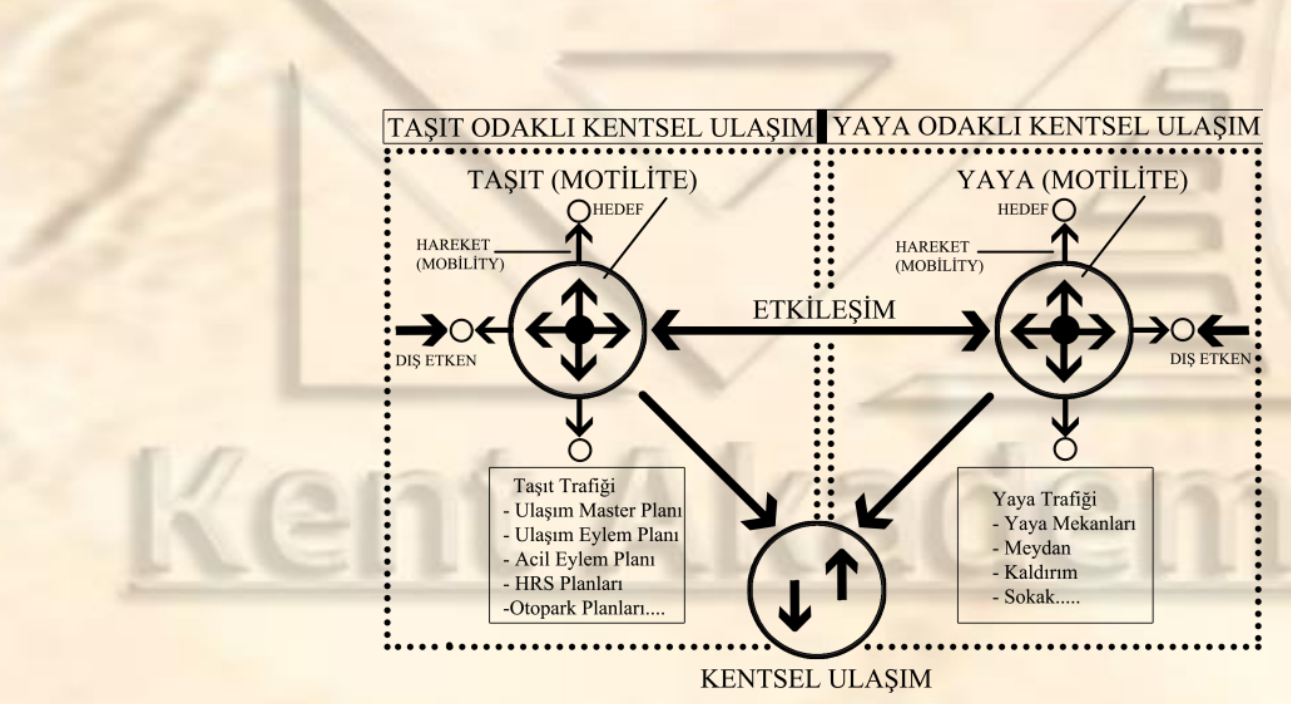

Şekil 4. Mobilite/Motilite Etkileşimi - Araç ve Yaya Odaklı Kentsel Ulaşım

\section{Kentsel Hareketlilik ve Sürdürülebilir Hareketlilik Planlaması}

Kentsel hareketlilik, fiziksel hareketliliğin bir parçası; aynı zamanda sosyal hareketlilikten de beslenen, kısa zamanda kent mekânında yapılmış olan yer değiştirme anlamına gelmektedir. Kentsel hareketlilik geniş bir çerçeve içerisinde tanımlanacak olursa, insanoğlunun gereksinimlerinden doğan fonksiyonların, kent mekânlarındaki yer değişimi ve bu fonksiyonları kullanan insanların kent mekânlarındaki hareketlerinin bileşimi, kentsel hareketliliği meydana 
getirmektedir (Kaygusuz, 2009). Kent mekânındaki bu hareketliliği iki şekilde ele almak mümkündür. Birincisi kentsel mekânların baş aktörleri olan insanın, kent mekânında yapmış olduğu hareketliliktir. İnsanoğlu sürekli değişme eğiliminde olup, bu değişimle birlikte gereksinimlerine göre mekânda hareketlilik kazanarak yeni gereksinimlerini karşılayacak mekân ya da mekânları tercih etmektedir. Bu hareketliliği bir örnekle ifade edecek olursak; eğitim çağına gelmiş bir çocuğun, eğitim gereksiniminden dolayı evi ve okulu arasında yapmış olduğu hareketlilik ya da bir insanın gereksinimlerinden dolayı mahallesi veya kent mekânı içinde yapmış olduğu hareketliliktir.

İkinci kentsel hareketlilik ise; kentsel fonksiyonların, sosyo-kültürel ve ekonomik nedenlerle kent mekânındaki hareketliliğidir. Bu hareketliliği de kendi arasında ikiye ayırabiliriz. Birincisi, yeni yerleşim alanlarının açılmasıyla bir kent fonksiyonunun alt fonksiyonlarının, bu yerleşim yerlerine kayması, merkez ve alt merkezdeki fonksiyonların zaman içinde rekabete girerek birbirlerinin yerlerini almasıdır. Bu hareketliliği bir örnekle ifade edecek olursak; kent merkezinde yer alan ticari fonksiyonların, kentin zamanla gelişmesiyle kurulan yeni yerleşim alanlarında da kendine yer seçmesi ve zaman içinde çeşitli ekonomik ve sosyal nedenlerle alt merkezdeki ticari fonksiyonların bireylerin gereksinimlerini karşılayacak daha iyi bir konuma gelmesiyle ana fonksiyona rakip olması ya da onun yerini almasıdır. Kent fonksiyonlarının kent mekânındaki hareketliliğinin ikincisi ise mekânın kent fonksiyonu için yetersiz kalması ya da fonksiyonun önemini yitirmesinden dolayı karar vericilerin ekonomik, sosyal ve yönetsel politikaları göz önüne alarak fonksiyonun yerini değiştirmesidir.

Kentsel hareketlilik konusunda da olduğu gibi, sürdürülebilir kalkınma kavramının etkisiyle kentle ilişkili tüm alanlarda sürdürülebilirlik çalışmaları öne çımaya başlamıştır. Bu kapsamda, ulaşım planlama araçları ve ilişkili tüm uygulama süreçlerinin de (özellikle iklim değişikliğinin olumsuz etkileri ile birlikte) sürdürülebilirlikle entegre edilmesi tartışılan konuların başında gelmektedir. Ulaşım sistemlerinin sağladığı faydaların yanında birçok olumsuz etkiyi de beraberinde getirdiği ve bu olumsuzluklar içerisinde büyük bir paya sahip olduğu bilinmektedir. Bu olumsuzlukların dengelenebilmesi ve azaltılması için yapılan çalışma ve uygulamalar "sürdürülebilir ulaşım" çatısı altında toplanmaktadır (Cirit, 2014).

Sürdürülebilir ulaşımdan yola çıkarak, sürdürülebilir hareketlilik kavramı, 1987 Birleşmiş Milletler (BM) "Ortak Geleceğimiz" raporunun sürdürülebilir kalkınma tanımına dayanmaktadır. Bu tanımda, sürdürülebilir kalkınma için "gelecek nesillerin kendi ihtiyaçlarını karşılayabilme yeteneğinden ödün vermeden bugünün ihtiyaçlarını karşılamaktır" denilmektedir (United Nations World Commission on Environment and Development, 1987). Sürdürülebilir hareketlilik, sürdürülebilir kalkınma prensiplerine bağlı kalarak bireylerin ulaşım taleplerini karşılama yollarını aramaktadır.

Sürdürülebilir hareketliliğin temelini oluşturduğu sürdürülebilir hareketlilik planlaması, kamu politika yapıcılarının sadece mevcut ulaşım talebini karşılamakla kalmayıp, aynı zamanda söz konusu talebin büyüklüğünü ve yapısını aktif bir şekilde yönlendirmeleri gerektiği yönünde varsayımlara dayanmaktadır (Czepkiewicz vd., 2016). Sürdürülebilir hareketlilik planlaması, bir anlamda koruyucu hekimliğe benzemektedir. Çünkü tıpkı koruyucu hekimlik uygulamalarında olduğu gibi, SKHP sorunların ortaya çıkıp artmasını beklemek yerine, ortaya çıkabilecek sorunları öngörmekte, yönetmekte ve önleyici çözüm öneriler sunmaktadır (Andrei ve Papuc, 2016). Değiş̧ime ve farklılığa odaklandığından dolayı ulaşım planlamasında önceki yaklaşımlardan daha iyi hedefler kümesi belirleyen sürdürülebilir hareketlilik planlaması, yeni bir paradigma olarak tanımlanmaktadır. Yeni paradigmadaki ana hedeflerden biri kentlerde motorlu seyahat miktarını azaltmaktır (Banister, 2007). Motorlu seyahatin azaltılması ve yaya, bisiklet ve toplu taşımanın yanı sıra hizmetlerin ve diğer arazi kullanımındaki değişikliklerin yakınlığının arttırılması yoluyla modal kayma sağlanmaya çalışılmaktadır (Banister, 2007).

Sürdürülebilir hareketlilik planlamasının ana hedefleri (Andrei ve Papuc, 2016); destinasyonlara ve temel hizmetlere erişmek için kent sakinlerine alternatif ulaşım seçenekleri sağlamak, ulaşımın güvenliği ve güvenilirliğini geliştirmek, sera gazı emisyonları, enerji tüketimi, hava ve gürültü kirliliğini azaltmak, ulaşımın verimliliğini, kentsel çevrenin ve kentsel peyzajın çekiciliğini ve kalitesini, kent sakinlerinin, ekonominin ve toplumun yararına arttırmaktır.

Sürdürülebilir hareketlilik planlaması, kentleri araştırmak ve arazi kullanımı ile ulaşım arasındaki bağları güçlendirmek için alternatif bir paradigma sağlamaktadır. Bu yeni paradigma yeni politika şemaları ve kavramları gerektirmektedir. $\mathrm{Bu}$ yeni kavramlardan biri, $\mathrm{AB}$ tarafından önerilen Sürdürülebilir Kentsel Hareketlilik Planı (Sustainable Urban Mobility Plan (SUMP)) kavramıdır. SKHP; kentlerde ve çevrelerinde daha iyi bir yaşam kalitesi için bugünün ve yarının insanlarının hareketlilik ihtiyaçlarını karşılayan sürdürülebilir, entegre ve katılımcı değerlendirme ilkelerini içeren stratejik bir plandır (Uluç, 2014). Hedefi ise "kentsel alanların erişilebilirliğini 
iyileştirmek ve kentsel alanlarda yüksek kaliteli ve sürdürülebilir hareketlilik ve ulaşım sağlamak" olarak ifade edilmektedir (European Commission, 2013). SKHP çerçevesinde, bazı Avrupa ülkeleri, Fransız "Plan De Déplacements Urbains" (Kentsel Seyahat Planı) veya İngiliz "Local Transportation Plans" (Yerel Ulaşım Planları) gibi kendi sürdürülebilir hareketlilik planlarını oluşturmuşlardır (Czepkiewicz vd., 2016).

Ulaşım planlamasında geleneksel yaklaşımlarla kıyaslandığında, sürdürülebilir hareketlilik planlaması bütüncül ve değişim odaklı bir yaklaşımdır. Odak, trafik ve altyapı yönetiminden, küresel çevre üzerindeki olumsuz etkiyi en aza indirmeye, yerel çevrenin kalitesini yükseltmeye, erişilebilirliği arttırmaya ve hareketlilik kalıplarını değiştirmeye yönelik hedeflere kaydırılmaktadır. İlgili tüm seyahat modları dikkate alınırken, ulaşım planlaması arazi kullanım politikaları ile entegre edilmektedir (Czepkiewicz vd., 2016).

\section{Sürdürülebilir Kentsel Hareketlilik Planları (SKHP) ${ }^{7}$}

BM verilerine (2014) göre dünya nüfusunun \%54'ünü barındıran kentler, (2050 yılı projeksiyonlarına göre bu oranın \%66'ya çıkması beklenmektedir) yenilik ve ekonomik büyümenin motoru konumundadır. İstihdam firsatları ve sosyal imkânlar insanları kırsal alanlardan kentlere çekmektedir. Konut ve işlevsel alanlara yönelik artan talebi karşılamak için kentler (özellikle gelişmekte olan ülkelerde) hızlı ve plansız bir biçimde büyümektedir. Büyüyen kentlerde ulaşım altyapısı artan nüfusun hareketlilik ihtiyaçlarını karşılayamamaktadır. Bireysel araç kullanımının artması, trafik sıkışıklığına, hava kalitesinin bozulmasına, halk sağlığının azalmasına, sosyal ayrımcılığa ve maliyetli yatırımlara neden olmaktadır. Arazi kullanımını ve ulaşım altyapısını planlamak ve yönetmek için etkili bir sisteme sahip kentler ise bu gelişimin, yaya, bisiklet ve toplu taşıma olanaklarıyla desteklenmesiyle yüksek yaşam kalitesinde olmasını sağlamaktadırlar. Bir kentin arazi kullanımı ve ulaştırma sistemi ile ilgili sürdürülebilir bir rota oluşturulması, kent için bir vizyon ortaya koyan, ulaşım sisteminin iyileştirilmesine öncelik veren, farklı paydaşların uygulamadaki sorumluluklarını açıklayan net bir yol haritası olan Kentsel Hareket Planları (Urban Mobility Plans (UMP)) ile mümkündür (Böhler vd., 2014).

Hareketlilik planları, yoğun kirlilik ve tıkanıklık seviyelerine, gereksiz enerji tüketimine ve planlama aktörlerinin dağılımındaki ekonomik ve sosyal verimsizliğe yerel bir tepki olarak ortaya çıkmıştır (European Metropolitan Transport Authorities, 2009). Kentsel hareketlilik planları, güvenli, verimli ve erişilebilir kentsel ulaşım sistemlerine yönelik hedefleri ve önlemleri içeren bir planlama aracıdır (Böhler vd., 2014). Bu planlar sürdürülebilir bir faaliyet olarak kendini geliştirmeyi, aynı zamanda ekonomik aktiviteleri desteklemeyi ve sosyal uyumu güçlendirmeyi esas almaktadır (European Metropolitan Transport Authorities, 2009).

Kentsel hareketlilik planı hazırlama süreci, aynı zamanda, farklı bir paydaş grubunun, kentlerdeki ulaşım sistemini iyileştirmek için ortak bir vizyon etrafında toplanmasını da gerektirmektedir (Böhler vd., 2014). Kentsel hareketlilik sistemlerinin performansı, bir toplumun kentsel yaşam kalitesini iyileştirmek amacıyla teknolojiyi en çok kullanan sürdürülebilir ulaşım modlarını tasarlama ve sunma ihtiyacı hakkındaki farkındalığını somutlaştırmaktadır (Dávila, 2013). Başarılı bir kentsel hareketlilik planı; yaşam kalitesini iyileştirmek, ekonomik faydalar yaratmak, daha sağlıklı bir çevrede kesintisiz hareketlilik ve erişimi iyileştirmek, sınırlı kaynakların daha verimli kullanılmasını sağlamak, kamu desteğini kazanmak, planlama sürecini iyileştirmek, yasal yükümlülükleri etkin bir şekilde yerine getirmek, plana alaka düzeyini ve katılımı arttırmak gibi temel hedeflere sahiptir (Andrei ve Papuc, 2016). Hareketlilik planları ve sürdürülebilirliğin temelini oluşturduğu SKHP, Avrupa Kentsel Hareketlilik Gözlemevi'ne (ELTIS) göre; kentlerde ve çevrelerindeki insanların ve işletmelerin daha iyi bir yaşam kalitesine sahip olabilmeleri için hareketlilik ihtiyaçlarını karşılamak üzere tasarlanmış stratejik bir plandır. Başka bir ifadeyle SKHP; sürdürülebilirlik taahhüdü ile işlevsel kentsel ve alt kentsel alanlar için insanların ve malların hareketliliğini planlayarak, insanların ve işletmelerin hareketlilik ihtiyaçlarını karşılamayı amaçlayan stratejik, uzun vadeli bir plandır (Mercatelli, 2016).

SKHP, disiplinler arası planlama ve politika analizini, karar verme süreci ile birleştiren kentsel çok modlu ulaştırma sistemi planıdır. Hedefleri, sürdürülebilir hareketliliğin bileşenleri ile örtüşmektedir ${ }^{8}$ (Pozoukidou vd., 2017). SKHP,

\footnotetext{
${ }^{7}$ SKHP İngilizcede "Sustainable Urban Mobility Plans" olarak kullanılmaktadır. Yabancı kaynaklarda "urban" kelimesi ile "kentsel" anlamı ifade edilmektedir (Tureng Türkçe İngilizce Sözlük, 2018). Bazı çeviri durumlarında "urban" kelimesi Türkçeye "kent içi” olarak çevrilmektedir. Ancak planlama disiplininde "kentsel" ile "kent içi" kavramları aynı anlama karşılık gelmemektedir. Yabancı kaynaklarda "kent içi" kavramı için "internal" (Cambridge Dictionary, 2018) kavramı kullanılmaktadır. Bu sebeple "Sustainable Urban Mobility Plans" için "urban" kelimesinin "kentsel" olarak tercüme edilmesi gerekmektedir.
} 
açık ve katılımcı bir yaklaşımla insanlara ve hareketliliğin insan ihtiyaçlarına odaklanmakta ve bireylerin sürecin ilk aşamalarından itibaren aktif katılımını içermektedir. SKHP, hareketlilik talebinin düzenlenmesine, trafik sıkışıklı̆̆ının azaltılmasına ve hareketlilik ücretlerine kadar, sürdürülebilir kentsel hareketlilik politikasının temel stratejilerini belirlemektedir (Comune di Rimini, 2016). SKHP yaklaşımının temel özelliği, ekonomik, sosyal ve çevresel hedefleri dengelemeyi amaçlayan, insanların ve malların kentsel hareketliliğine bütünsel bir yaklaşımdır (Rudolph vd., 2015). SKHP yaklaşımının bir diğer önemli özelliği, planlama sürecinin çeşitli aşamalarında paydaşlar arasında işbirliğini ve uzlaşma oluşumunu desteklemesidir (Pozoukidou vd., 2017).

SKHP tek başına kentin karşı karşıya kaldığı tüm problemleri çözebilen bir araç değildir. Ayrıca, sadece ulaşımla alakalı bir strateji, kopyala yapıştır bir yaklaşım veya anti-araç propagandası olarak da görülmemelidir. SKHP geliştirmekte önemli olan plan değil sürecin kendisidir. Çünkü SKHP, kentsel alanlardaki sorunları stratejik olarak ele almaktadır. Durum analizi, vizyon oluşturma, objektif hedef belirleme, politika ve ölçü seçimi, aktif iletişim, izleme ve değerlendirme gibi süreçleri ele alan yapılandırılmış bir planlama çalışmasıdır. Bir SKHP'nin özellikleri; uzun vadeli vizyon ve uygulama planına sahip olması, paydaşların ve halkın katılımını sağlaması, daha sürdürülebilir modlara geçişi teşvik eden ilgili tüm ulaşım modlarının dengeli gelişimini teşvik etmesi, yönetim ve politikacılarla, politika sektörleri ve yakınındaki yerleşim birimleriyle yüksek düzeyde entegrasyon ve işbirliği kurgulaması, somut ve iddialı, fakat ulaşılabilir, zamana bağlı ve diyalog süreci sonucunda ortaya çıkmış olan hedeflerin belirlenmesine yönelik mevcut performans ve ulaşım sorunlarını değerlendirmesi, düzenli izleme, gözden geçirme ve raporlama aşamalarına sahip olması ve tüm ulaşım modları için harici maliyetleri göz önünde bulundurmasıdır (Böhler vd., 2014). SKHP'nin amacı, kentsel alanların erişilebilirliğini iyileştirmek ve kentsel alan boyunca ve içinde yüksek kaliteli, sürdürülebilir hareketlilik ve ulaşım sağlamaktır. SKHP, kentsel alanın gelecekteki gelişimi için mevcut ve uzun vadeli bir strateji ile bağlantılıdır. Bu bağlamda, ulaşım ve hareketlilik altyapısının ve hizmetlerinin gelecekteki gelişimi için hazırlanmaktadır. SKHP, aynı zamanda, kısa vadeli stratejiler de içermektedir. Kısa ve uzun vadede ele alınan stratejiler için zaman aralığı genellikle 3-10 yıllık bir dönemi kapsamaktadır (European Cities and Regions Networking for İnnovative Transport Solutions, 2013). SKHP'nin başlıca amaçları aşağıda verilen tablodaki gibidir (Tablo 1) (Böhler vd., 2014);

Tablo 1. Sürdürülebilir Hareketlilik Planlarının Amaçları

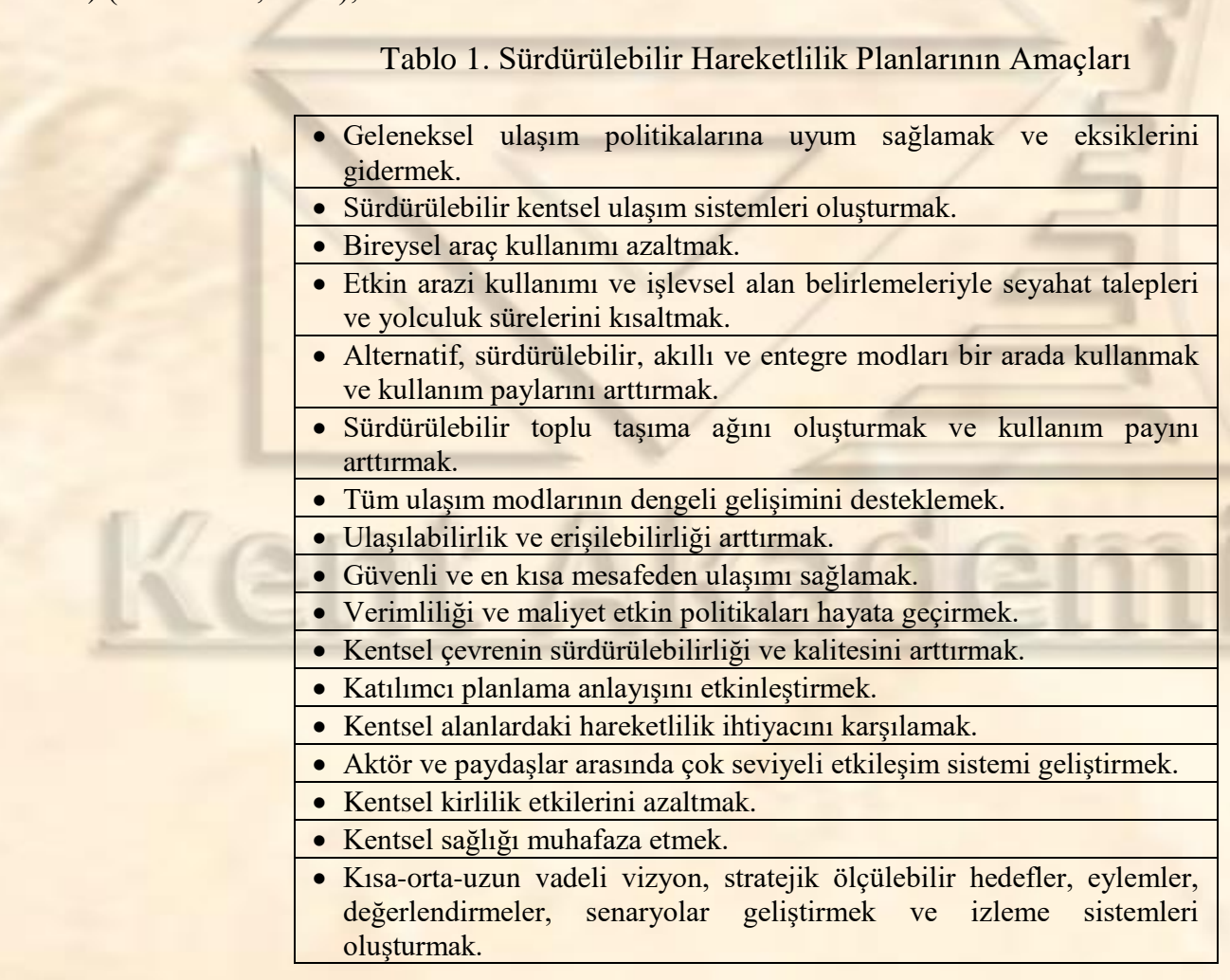

\footnotetext{
${ }^{8}$ Örneğin; verimli ve ekonomik mobilite hizmetleri, güvenliğin arttırılması, emisyonların azaltılması, enerji verimliliğinin arttırılması, kentsel çevrenin iyileştirilmesi, erişilebilirlik vb. hazırlık ve hedef belirleme aşamalarından detaylandırma ve uygulama/değerlendirme aşamalarına kadar bir dizi aktiviteden oluşan, bir dizi unsur aracılığıyla tüm planlama sürecini kapsamaktadır (Pozoukidou vd., 2017).
} 
Geleneksel ulaşım planlamasına kıyasla, SKHP, ulaştırma sisteminin verimliliğinin en üst düzeye çıkarılmasını ve ulaşım dışsallıklarının en aza indirilmesini amaçlayan bütünsel bir yaklaşımdır ${ }^{9}$. Geleneksel ulaşım planlaması genellikle "tahmin et ve çözüm üret" olarak bilinen bir yaklaşımı izlemektedir. Planlamacılar, geçmiş eğilimlere dayalı olarak kişisel motorlu araçların kullanımında gelecekteki büyümeyi tahmin etmekte ve bu büyümeyi karşılamak için ihtiyaç duyulan altyapı gereksinimlerini hesaplamaktadırlar ${ }^{10}$ (Böhler vd., 2014). Geleneksel ulaşım planlaması yaklaşımları, ulaşım altyapısını genişleterek araçların hareketine odaklanmaktadır. Ancak doğru olan tüm nüfus grupları için hareketlilik ve erişilebilirlik üzerinde durulmasıdır. Aşağıdaki tabloda, geleneksel ulaşım planlaması, SKHP ile karşılaştııılmaktadır (Tablo 2);

Tablo 2. Sürdürülebilir Hareketlilik Planları İle Geleneksel Ulaşım Planlarının Kıyaslanması

\begin{tabular}{|c|c|}
\hline Geleneksel Ulaşım Planlaması & Sürdürülebilir Kentsel Hareketlilik Planları \\
\hline - Trafik odaklı planlama. & - Bireylere ve aktivitelere odaklı planlama. \\
\hline $\begin{array}{l}\text { - Amaç: T1kanıklığı azaltmak ve hızı arttırmak, } \\
\text { - Öncelikli hedefleri: Trafik akış kapasitesi ve hızı, } \\
\text { - Hedeflere eksik veya geniş açıdan odaklanmak. }\end{array}$ & $\begin{array}{l}\text { - Amaç: Erişilebilirlik, yaşanabilirlik ve kamusal alanların } \\
\text { kalitesini arttırmak, } \\
\text { - Öncelikli hedefleri: Erişilebilirlik, yaşam kalitesi, } \\
\text { sürdürülebilirlik, ekonomik canlılık, sosyal eşitlik, sağlık } \\
\text { ve çevre kalitesi, } \\
\text { - Ölçülebilir sonuçlar ve hedeflerin başarılmasına } \\
\text { odaklanmak. }\end{array}$ \\
\hline - Modal odaklanma (belirli ta & $\begin{array}{l}\text { - İlgili tüm ulaşım modlarının dengeli gelişimi, daha temiz } \\
\text { ve sürdürülebilir ulaşım modlarına geçiş. }\end{array}$ \\
\hline - Ulaşım ve altyapı od & $\begin{array}{l}\text { - Uygun maliyetli çözümler elde etmek için entegre } \\
\text { eylemler kümesi, } \\
\text { - Sosyal eşitliği, çevresel kalite ve ekonomik kalkınmayı } \\
\text { dengeleme ve politika sektörleri (çevre, arazi kullanımı } \\
\text { vb.) arasında uygulama ve politikaların entegrasyonu. }\end{array}$ \\
\hline $\begin{array}{l}\text { - Sektörel veya belirli bir kente odaklı ve paydaşların } \\
\text { katılımı sınırlı. }\end{array}$ & $\begin{array}{l}\text { - İlgili politika alanlarını (arazi kullanımı, mekânsal } \\
\text { planlama, sosyal hizmetler, sağlık, vb.) tamamlayan } \\
\text { yüksek paydaş katılımlı planlama. }\end{array}$ \\
\hline $\begin{array}{l}\text { - Kısa ve orta vadeli bir bakış açısıyla stratejik bir vizyon } \\
\text { ve plan. }\end{array}$ & $\begin{array}{l}\text { - 20-30 yıllık bir süreçte uzun vadeli bir vizyona gömülen, } \\
\text { kısa ve orta vadeli strateji ve plan. }\end{array}$ \\
\hline - Teknik özelliklere ve trafik mühendisliğine öncelik. & $\begin{array}{l}\text { - Disiplinler arası planlama ekipleriyle entegre planlamaya } \\
\text { öncelik; bölge, trafik, çevre vb. }\end{array}$ \\
\hline - Uzmanlarla planlama. & • Paydaşların şeffaf ve katılımcı bir yaklaşımıyla planlama. \\
\hline - Yetki katmanları arasında işbirliği yetersizliği. & $\begin{array}{l}\text { - Yönetimin katmanları arasındaki entegrasyon (bölge } \\
\text { kurulu, belediye vb.) }\end{array}$ \\
\hline - Geleneksel yol ağı ve altyapının geliştirilmesi. & $\begin{array}{l}\text { - Toplu taşımayı, yürümeyi, bisiklete binmeyi teşvik etmek } \\
\text { ve bu yönde önlemler almak. }\end{array}$ \\
\hline - Maliyet faydalarının göz ardı edilmesi. & $\begin{array}{l}\text { - Ulaştırma maliyetlerinin ve faydalarının politika } \\
\text { sektörlerinde de gözden geçirilmesi. }\end{array}$ \\
\hline - Sınırlı etki değerlendirmesi. & $\begin{array}{l}\text { - Yapılandırılmış bir öğrenme ve iyileştirme sürecini elde } \\
\text { etmek için etkilerin düzenli olarak izlenmesi ve } \\
\text { değerlendirilmesi. }\end{array}$ \\
\hline - Büyük kaynaklar gereksinen proje. & • Kaynak kullanımında limit kavramı. \\
\hline - Siyasi yönetim ve kilit roldeki teknik personelin katılımı. & - Katılımcı süreçler: Paydaşlar ve kent sakinlerinin rolü. \\
\hline
\end{tabular}

(Böhler vd., 2014, 9; May, 2015, 2; Mercatelli, 2016, 6’dan yararlanılarak geliştirilmiştir.)

\footnotetext{
${ }^{9}$ SKHP önlemleri arasında, temiz yakıt kullanımı, talep yönetimi stratejileri arasında hareketlilik yönetimi, toplu taşıma, ulaştırma telematiği ve araç bağımlılığı azaltma stratejileri vb. müdahaleler bulunmaktadır.

${ }^{10}$ Bugün, ulaşım plancıları, bir kentin yaptığı altyapı yatırım seçimlerinin, sakinlerinin seyahat davranışları üzerinde büyük bir etkisi olduğunu giderek daha fazla fark etmektedirler. Yürüme, bisiklete binme ve toplu taşıma gibi sürdürülebilir ulaşım modlarına daha fazla önem verilmesi, sadece bireylerin sağlığıyla sınırlı olmamak üzere birçok anlamda geniş kapsamlı faydalar getirmektedir (Böhler vd., 2014).
} 
Tabloda yer alan verilerden hareketle geleneksel ulaşım planlamasının, bireysel araç kullanımını öne çıkaran trafik odaklı bir planlama anlayışı ile belirli kent ve bölgelerde fiziksel ulaşım altyapısının iyileştirilmesi ve genişletilmesi yoluyla ulaşım problemlerine çözüm ürettiği anlaşılmaktadır. Ayrıca geleneksel ulaşım planlaması, yapılacak yeni ulaşım yatırımları sebebiyle büyük kaynaklar gereksinmekte, plan süreci yalnızca alanında uzman kişilerden oluşan bir ekiple ve teknik bakış açısıyla yönetilmekte, kent sakinlerinin ve süreçte rol alabilecek ilgili kilit aktörlerin katılımı sınırlı kalmaktadır. SKHP geleneksel ulaşım planlarının aksine, bireyi öne çıkaran insan odaklı planlama anlayışı ile ilgili tüm yerleşim birimleri ve politika alanlarında, erişilebilirliği, yaşanabilirliği ve kamusal alanların kalitesini arttırmaktadır. SKHP, erişilebilirlik, yaşam kalitesi, sürdürülebilirlik, ekonomik canlılık, sosyal eşitlik, sağlık ve çevre kalitesi hedeflerini önceliklendirmekte, ilgili tüm ulaşım modlarının dengeli gelişimini sağlayarak daha temiz ve sürdürülebilir ulaşım modlarına geçişi teşvik etmektedir. Ayrıca SKHP kısa vadede geçici çözümler üretmemekte, 20-30 yıllık bir süreçte uzun vadeli bir vizyona gömülen, kısa ve orta vadeli stratejiler geliştirmektedir. SKHP, sosyal eşitliği, çevresel kalite ve ekonomik kalkınmayı dengeleme ve politika sektörleri arasında uygulama ve politikaların entegrasyonu sağlamakta, disiplinler arası planlamaya öncelik vermekte, paydaşların katılım süreçlerini sağlıklı işletmektedir.

\section{SONUÇ VE TARTIŞMA}

Kentlerin; kalkınma ve gelişme dinamiklerinin odağı olduğu düşünüldüğünde, yaşanabilirlik, yaşam kalitesi ve sürdürülebilirlik gibi kavramların daha da önem kazandığı görülmektedir. Bu çerçevede kentleşme, kentsellik ve kentsel yapı iç içe geçmekte, sürdürülebilir ve yaşanabilir kentler ve mekânlar ön plana çıkmaktadır. Böylece kentsel yapının her türden bileşeni, sosyal, ekonomik, mekânsal, kültürel, idari, akçal, çevresel, teknolojik vb. bileşenlerle tariflenmekte, sürdürülebilirlik ve yaşanabilirlik alan kullanım stratejilerinin ve politikalarının da asal nesnesi olmaktadır. Bu bileşenlerin en önemlilerinden biri olan sürdürülebilir kentsel ulaşım politikalarının temel amacı da kentsellik ve kentleşme ile olan ilişkide özellikle kentsel seyahatlerde bireysel araç kullanımının azaltılması, sürdürülebilir ulaşım modlarının yaygınlaştırılması aracılığıyla kaliteli toplumsal ve kentsel ağın oluşturulmasıdır.

Dünyada kentsel hareketliliğin sadece araç odaklı hareketlilik olarak algılanmaması, erişilebilirliğin sağlanması ve kişisel motorlu araçlara olan bağımlılığın neden olduğu olumsuz etkilerin azaltılması için sürekli olarak sürdürülebilir kentsel ulaşım alternatifleri geliştirilmektedir. Hâlihazırda benimsenen alternatiflerden biri SKHP'lerdir. Geleneksel ulaşım planları yerine geliştirilen SKHP insan odaklı bütünleşme süreçlerini ele almaktadır. SKHP kentlerin zaman içerisinde geçirdiği değişimler doğrultusunda sürekli değişen esnek planlardır. Bu planlar, tüm nüfus gruplarının hareketlilik ihtiyaçlarına stratejik olarak odaklanarak, geleneksel planlama süreçlerinin kapsamını sürdürülebilir olarak genişletmektedir. Avrupa'da bu planlar araştırma, uygulama ve fonlama aşamalarında; Birleşmiş Milletler Dünya Çevre ve Kalkınma Komisyonu, Avrupa Birliği, Avrupa Komisyonu, Ekonomik İş Birliği ve Kalkınma Örgütü, Sürdürülebilir Ulaşım Merkezi, Dünya Kaynakları Enstitüsü vb. örgüt ve kurumlar ile ilgili yerel yönetim birimlerinin girişimleri ve katkısıyla desteklenmekte ve yaygınlaştırılmaktadır.

Dünya uygulamalarının aksine bu yeni planlama anlayışı Türkiye'de yeterince araştırılmamakta ve Türkiye'ye özgün SKHP uygulamalarını ortaya koymayı hedefleyen çalışmalar henüz başlangıç aşamasındadır ${ }^{11}$. Türkiye'de birçok kurum kentsel ulaşım politikaları kapsamında plan ve uygulama süreçlerinde yetki ve sorumluluklara sahip olup, etkin ve bütüncül bir yönetim ağıyla yönetilmesi gereken bu süreç verimli işletilememektedir. Ayrıca sürdürülebilir ulaşımın ana unsurlarından biri olan motorsuz ulaşım modlarının kullanımının arttırılması konusunda Türkiye'deki mevcut durum istenen düzeyde değildir. Bu sebeple Türkiye'de de ulaşımın temelini oluşturan hareketlilik; kentler, kent sakinleri ve gelecek nesillerin teminatı konumundaki yaşanabilirlik ve sürdürülebilirlik ilkeleri ile birlikte güncel ulaşım çözümlemelerinde ele alınmalıdır. Özellikle modern anlamda ulaşım ve altyapı çözümlemeleri sürdürülebilir hareketliliği esas kabul eden anlayışla oluşturulmalıdır.

Türkiye’ye özgün SKHP geliştirme süreci ve çalışmaları, daha önce başka ülke ve kentlerde işletilen süreç ve yapılan çalışmaları referans veren benzerlikte olmamalıdır. SKHP süreçleri, uygulanması istenilen kente özgün olmalı ve kente ait maksimum nüfus projeksiyonunun belirlenmesinin ardından kısa ve orta vadeli etaplamalar içeren uzun vadeli stratejilerle ele alınmalıdır. SKHP'nin önemli aşamalarından biri olan izleme, değerlendirme ve plan revizyon süreleri de yine o kente özgün olarak plan geliştirme sürecinin en başında belirlenmelidir. Başka ülke ve kentlerde yapılan SKHP ve uygulama süreçlerinde kullanılan analiz ve sentez yöntemleri birebir uygulanmamalıdır. Türkiye'ye özgün analiz ve sentez yöntemleri, ilk olarak ulusal stratejik bir rehberle belirlenmeli ardından plan muhatabı kente özgün süreçlerle teknik yöntemler geliştirmelidir.

${ }^{11}$ Türkiye'de bununla birlikte, sürdürülebilir uygulamaları mevcut ulaşım planlarına entegre etmeyi hedefleyen adımlar atılmaya çalışılmaktadır. 
SKHP geliştirme süreci kent makroformunun mevcut durumuyla da ilişkilendirilmelidir. Özellikle Türkiye'de lineer gelişme eğilimi gösteren kentlerde SKHP geliştirme sürecinin nasıl işletileceği araştırılmalı ve tartışılmalıdır. Türkiye'de artan bireysel araç kullanımı, motorsuz modların kullanım payının az olması ve aynı zamanda toplu taşıma ağının verimsiz ve yetersizliği göz önüne alındığında, SKHP geliştirme sürecinin kentlerde nasıl işletileceği, etaplanacağı ve ne tür önlemler alınacağı belirlenmelidir. SKHP aracılığı ile bireysel araç kullanımının verimli olduğu hareketlilik sistemleri zarar görmemeli, ihtiyaç olduğu bölgelerde bireysel araç kullanımının verimliliği sağlanmalıdır.

SKHP aynı zamanda işlevsel alan kullanımlarının belirlenmesi, imar planı sürecinin tamamlanması ve birçok sektöre ait parçacıl planların bir araya getirilmesini sağlamaktadır. Buradan hareketle Türkiye'de SKHP geliştirilebilmesi için ilk olarak planlama ve uygulama yasal hiyerarşilerinde ve mevzuatlarında gerekli değişikliklerin yapılması gerekmektedir.

SKHP bireyleri öne çıkarıp, kent sakinlerinin ve diğer ilgili paydaşların plan sürecine katılımını sağlasa da, plan geliştirme süreci, ilgili ve daha önceden belirlenen uzman bir ekibin danışmanlığında yürütülmelidir. SKHP yerel yönetim birimleri tarafından oluşturulmalı, ulusal kurum ve kuruluşlarca fonlanmalıdır. Bu sayede gerekli süreçlerin işletilmediği ve uzman bir ekibin kontrolünde katılımcı bir anlayışla yapılmayan tüm planlar gerçekleşme imkânı bulamayacaktır. Ayrıca Türkiye'de katılımcı planlama sürecinin etkin bir şekilde işletilmesi için gerekli düzenleme ve uygulamalar da yapılmalıdır.

Türkiye'de işletilen kent planlama süreçleri ulaşım planlama araçlarını da içerisinde barındırmaktadır. Ancak SKHP geliştirme sürecinde, kentin planlanması ve planın uygulanması sürecinin ardından ortaya çıkan ulaşım problemleri bu planlarla mı giderilmeli yoksa ilk olarak sürdürülebilir hareketlilik göz önünde bulundurularak ulaşım planlaması yapılmalı ve sonucunda işlevsel alan kullanımlarının yeri ve imar uygulama süreçleri bu doğrultuda mı yürütülmelidir tartışması yapılmalıdır.

SKHP geliştirme sürecinde Türkiye'deki kentlerin toplumsal yapısı da incelenmeli, SKHP'nin kent sakinleri tarafından kabul edilebilirliği analiz edilmelidir. SKHP geliştirilirken bir kentin öne çıkan sektörleri üzerine yoğunlaşan anlayışla plan yapılmamalı, hareketlilik planlarının kapsamlı ve çok boyutlu yönü kentin tüm özellikleri için işletilmelidir. Tüm bu gelişmelerin yanı sıra kentlerin teknolojik durumları incelenmeli, SKHP kentin teknolojik seviyesiyle uyum göstermeli ve aynı zamanda SKHP uygulama süreçleri masa başında alınan kararların arazide ki yansımalarının düzenli takibiyle sürekli olarak geliştirilmeli ve eksiklikleri giderilmelidir.

SKHP süreçleri birbirinin kopyası olacak şekilde ayrı ayrı tüm kentler için uygulandığında nüfus, teknoloji, ekonomi, toplumsal yapı, doğal çevre, sektörler vb. kentten kente farklılaşan birçok etken sebebiyle verimlilik gösterememektedir. SKHP geliştirme sürecinde özellikle kentlerin büyümesinin sınırlandırılması ve kompakt kent elde edilmeye çalışılması sayesinde kentin sahip olduğu doğal alanlar ve üretim alanları da korunmalıdır.

SKHP kent sakinlerinin sağlığını arttıracak önlemleri de içermelidir. Bireysel araç kullanımının azaltılması, etkin arazi kullanımı ve kompakt kent modelinin geliştirilmesi süreçlerinin doğrudan etkisiyle kentte sera gazı emisyonları ve çeşitli kirlilik düzeyleri azaltılmaktadır. Bu bağlamda kent sakinleri olumsuz iklim değişikliği etkilerine en az seviyede maruz kalmaktadır. Aynı zamanda SKHP uygulama süreçleriyle birlikte işletilen doğal çevre ve kaynakların da korunmasıyla kent sağlı̆g arttırılmaktadır.

Sonuç olarak, artan nüfus, ulaşım talebi, bireysel araç kullanımı ve dolayısıyla iklim değişikliğinin olumsuz etkilerinin oluşturduğu baskının, sürdürülebilir ve yaşanabilir kentlerin oluşturulması için yapılan çalışmalar ışığında, Türkiye'deki kentlere özgün ve ayrı ayrı SKHP'ler vasıtasıyla yönetilmesi ve planlanması gerekmektedir. 


\section{KAYNAKÇA}

\section{Bildiri, Rapor ve Teknik Dokümanlar}

Andrei, C.A., Papuc, E.I., (2016), A Sustainable Urban Mobility Plan Solution for a City of the Future?, The 4th International Conference of the NORD Events, Rethinking Global Space, Culture and Change in Organizations, The Bucharest Academiy of Economic Studies, Romania, s. 1-5.

Cirit, F., (2014), Sürdürülebilir Kentiçi Ulaşım Politikaları ve Toplu Taşıma Sistemlerinin Karşılaştırılması, T.C. Kalkınma Bakanlığı, Uzmanlık Tezi, s. 9-103.

Comune di Rimini, (2016), Sustainable Urban Mobility Plan, Infrastructure and Mobility Area Mobility Office, s 2.

European Cities and Regions Networking for İnnovative Transport Solutions, (2013), The Urban Mobility Package "Together Towards Competitive and Resource Efficient Urban Mobility, Adopted by the European Commission On 17.12.3013, s 2 .

European Commission, (2013), A Concept for Sustainable Mobility Plans, Brussels, Retrieved:http://ec.europa.eu/transport/themes/urban/doc/ump/com(2013)913-annex_en.pdf, s 2.

European Metropolitan Transport Authorities, (2009), Mobility Plans: The Way Forward for a Sustainable Urban Mobility, Paris, 1-5. Accessed on: 10.06.2018, Available at: https://www.emta.com/IMG/pdf/EMTAbried_2_basse_def_.pdf

Kaygusuz, S., (2009), Mersin'de Kentsel Hareketlilik: Mersin Esnafinın Mekânsal Hareketliliği Üzerine Bir Araştırma, Mersin Üniversitesi Sosyal Bilimler Enstitüsü, Yüksek Lisans Tezi, s. 30-32.

Kaynak, Z., (2005), Kentsel Alanlarda Ulaşım Politikaları ve Ulaşımda Sürdürülebilirlik, Gazi Üniversitesi Fen Bilimleri Enstitüsü, Yüksek Lisans Tezi, s 25.

Kjærulff, A.A., (2011), Motility Finding a Way to Mobility Attitude and Behavior, Proceedings From the Annual Transport Conference at Aalborg University, ISSN: 1603-9696, Available at: www.trafikdage.dk/artikelarkiv, s. 1-9.

Mercatelli, L., (2016), Sustainable Urban Mobility Plans European Practice, European Unions Horizon 2020 Research and Innovation Programme, Italy, s. 3-6.

Özübal, C.O., (2009), Bergama Örneğinde, Kentsel Açık Mekânlarda Yaya Hareketlerinin Çözümlenmesi Konusunda Bir Yöntem, Yıldız Teknik Üniversitesi Fen Bilimleri Enstitüsü, Yüksek Lisans Tezi, s 10.

Uluç, A., (2014), A Framework for Sustainable Urban Mobility in Historic Urban Landscape: A Proposal for Antalya Kaleiçi, A Thesis Submitted to the Graduate School of Natural and Applied Sciences of Middle East Techical University, s 48.

United Nations World Commission on Environment and Development, (1987), Report of the World Commission on Environment and Development: Our Common Future, Available at: http://www.un-documents.net/our-commonfuture.pdf, s300.

Yerli, G., (2015), Sürdürülebilir Kent İçi Hareketlilik Planları (SUMP) Çalıştay Raporu, Dünya Kaynakları Enstitüsü Ross Sürdürülebilir Şehirler Merkezi, s 2.

\section{Kitaplar}

Böhler, S., Kost, C., Merforth, M., Kumar, K., (2014), Urban Mobility Plans National Approaches and Local Practice Moving Towards Strategic, Sustainable and Inclusive Urban Transport Planning, Sustainable Urban Transport Technical Document \#13, Federal Ministry for Economic Cooperation and Development, s. 5-62. 
Czepkiewicz, M., Brudka, C., Jankowski, P., Kaczmarek, T., Zwolinski, Z., Mikula, L., Bakowska, E., Mlodkowski, M., Wojcicki, M., (2016), Public Participation GIS for Sustainable Urban Mobility Planning: Methods, Applications and Challenges, Rozwoj Regionalry i Polityka Regionalna, 35:9-35, s. 2-5.

Dávila, D.J., (2013), Urban Mobility \& Poverty Lessons from Medellín and Soacha, Colombia, Development Planning Unit, UCL \& Faculty of Architecture, Universidad Nacional de Colombia, ISBN 978-0-9574823-3-3 PDF, ISBN 978-0-9574823-2-6,Paperback, s. 1-216.

\section{Makaleler}

Banister, D., (2007), The Sustainable Mobility Paradigm, Transport Policy, 15(2008), 73-80, Elsevier, Transport Studies Unit, Oxford University Centre for the Environment, Oxford, UK, s. 6-7.

Flamm, M., Kaufmann, V., (2006), Operationalising the Concept of Motility: A Qualitative Study, Mobilities, 1:2, 167-189, DOI: 10.1080/17450100600726563.

Kaufmann, V., (2012a), Mobility, Mobile Lives Forum, Accessed on: 05.06.2018, Available at: http://en.forumviesmobiles.org/marks/mobility-450

Kaufmann, V., (2012b), Movement, Mobile Lives Forum, Accessed on: 05.06.2018,Available at: http://en.forumviesmobiles.org/marks/movement-460

Kaufmann, V., (2012c), Motility, Mobile Lives Forum, Accessed on: 06.06.2018, Available at: http://en.forumviesmobiles.org/marks/motility-461

Kaufmann, V., (2016), Mobility, Motility: What Determines Our Ability to Move?, Mobile Lives Forum, Accessed on: 05.06.2018, Available at: http://en.forumviesmobiles.org/video/2016/06/07/mobility-motility-wgat-determines-ourability-move-3260

May, D. A., (2015), Encouraging Good Practice in the Development of Sustainable Urban Mobility Plans, Elsevier, Case Studies on Transport Policy 3(2015), 3-11, s 2.

Ohnmacht, T., Maksim, H., Bergman, M.M., (2009), Mobilities and inequality: Making connections, Mobilities and Inequality, 7-26, Available at: : https://www.researchgate.net/publication/37468344

Özalp, M., Öcalır, V. E., (2008), Türkiye'deki Kentiçi Ulaşım Planlaması Çalışmalarının Değerlendirilmesi (1). METU JFA 2008/2, (25:2) 71-97, 1-27.

Pozoukidou, G., Gavanas, N., Verani, E., (2017), Land Use Models and Sustainable Urban Mobility Plans: An Integrative Approach for Strategic Planning, 867-882, s. 2-8.

Rudolph, F., Black, C., Glensor, K., Hging, H., Lah, O., McGeever, J., Mingardo, G., Parkhurst, G., Plevnik, A., Shergold, I., Streng, M., (2015), Decision-Making in Sustainable Urban Mobility Planning: Common Practice and Future Directions, World Transport Policy and Practice, 21(3), 54-64, ISSN 1352-7614, Available from: http://eprints.uwe.ac.uk/28625, http://worldtransportjournal.com/wp-content/uploads/2015/11/29th-Oct-opt.pdf, s 2.

\section{Sözlükler}

Cambridge Dictionary, (2018), Erişim Tarihi: 02.06.2018.

https://dictionary.cambridge.org/dictionary/english/move,https://dictionary.cambridge.org/tr/s\%C3\%B6zl\%C3\%BCk/ ingilizce/mobile,https://dictionary.cambridge.org/tr/s\%C3\%B6zl\%C3\%BCk/ingilizce/ability,https://dictionary.cambri dge.org/tr/s\%C3\%B6zl\%C3\%BCk/ingilizce/object,https://dictionary.cambridge.org/dictionary/english/internal,https:// dictionary.cambridge.org/dictionary/english/external?q=EXTERNAL

Dictionary, (2018), Erişim Tarihi: 02.06.2018. http://www.dictionary.com/browse/vulgus

Etimoloji Sözlüğü, (2018), Erişim Tarihi: 02.06.2018. 
https://www.etimolojiturkce.com/kelime/mobil,https://www.etimolojiturkce.com/kelime/hareket

Etymology Dictionary, (2018), Erişim Tarihi: 02.06.2018. https://www.etymonline.com/word/mob

İngilizce Latince Sözlük, (2018), Erişim Tarihi: 02.06.2018. https://ingilizce-latince.cevirsozluk.com/51218745motion\#la|tr|motio

Macmillian Dictionary, (2018), Erişim Tarihi: 02.06.2018.

https://www.macmillandictionary.com/dictionary/british/mobility

Quia Web, (2018), Erişim Tarihi: 02.06.2018. https://www.quia.com/jg/2816350list.html

Tureng Türkçe İngilizce Sözlük, (2018), Erişim Tarihi: 02.06.2018. http://tureng.com/tr/turkce-ingilizce/urban

Türk Dil Kurumu, (2018), Erişim Tarihi: 02.06.2018.

http://www.tdk.gov.tr/index.php?option=com_gts\&kelime=DEV\%C4\%B0N\%C4\%B0M,http://www.tdk.gov.tr/index. php?option=com_gts\&kelime=NESNE,http://www.tdk.gov.tr/index.php?option=com_gts\&arama=gts\&guid=TDK.G TS.5b1cf4ff445f98.57544560

Türkçe Terimler Sözlüğü, (2018), Erişim Tarihi: 02.06.2018. http://www.sozce.com/nedir/90675-devinim, http://www.kursunkalem.com/biyoloji-terimi/hareket/ 